\title{
RETHINKING RELIGION AND LANGUAGE IN NORTH INDIA: THE HINDI-URDU DISPUTE AND THE RISE OF RIGHT-WING POPULISM
}

\author{
William Gould \\ University of Leeds
}

\begin{abstract}
In 1930s and 1940s Uttar Pradesh, the question of the relationship between Hindi and Urdu in debates about a possible 'national' language has been widely assumed to interface with a politics of communal antagonism between Hindus and Muslims. However, the politics of figures on the 'left' of the Congress in this period suggest that the role of language in relation to religious antagonism was complex and sometimes paradoxical. We will explore the ways in which characteristics of the two languages were associated with particular forms of social and political behaviour, and how these associations between language and behaviour came to characterise the rise of Hindi.
\end{abstract}

Keywords: Communalism, Hindi, Language policies, Urdu.

\section{RESUMEN}

Durante las décadas de 1930 y 1940 en Uttar Pradesh los debates sobre la primacía del hindi o el urdu como la lengua oficial, 'nacional' se solapaban en gran parte con el enfrentamiento entre hindúes y musulmanes. Atendiendo a la postura que adoptó la 'izquierda' del Partido del Congreso, vemos que la relación entre lengua e identidad religiosa es bastante compleja y en ocasiones paradójica. En este artículo exploramos cómo las características de sendos idiomas se asociaban a determinado comportamiento social y político y cómo de esa correlación de fuerzas surgió la hegemonía del hindi.

Palabras clave: Hindi, Política lingüística, Sectarismo religioso, Urdu. 
On 6 January 1936, in reaction to Gandhi's attempts to promote Hindustani in both scripts - Persian and Devanagri- within the Hindi Sahitya Sammelan (hereafter HSS), ${ }^{1}$ the newspaper Sudha described the Mahatma as a 'blind devotee of Muslims'. Because of Gandhi's pious wishes it reported, poor Hindi would have to put on an awkward half-rustic, half Muslim costume and would be 'cremated'. Hindi, it claimed, was 'sansrkit's daughter and the language of cow protecting, non-violent image worshipers who considered India their only land.' How could it come to terms, Sudha argued, with the communalist language of cow-eating image destroyers, who considered Arabia and Iran their motherland, and whose foreign culture was violent, brutal and harking back to the days of Muslim empires? ${ }^{2}$

The image-laden reaction of Sudha provides a snapshot into one of the most important political divisions of late colonial India - a debate that had clearly emerged in the north of the country's mainstream media by the mid 1930 s, around the issue of script and language. What we might describe as the 'Hindi world' - the sphere of politics and culture that sought to promote the idea of a single national vernacular - was split into two camps. On the one side a 'Hindustani' group, promoting a language which recognized the mixed scriptural and vocabulary bases of Hindi and Urdu as conjoined languages. This included the likes of Rajendra Prasad, Jawaharlal Nehru, Vinoba Bhave, Kaka Kalelkar, Rajagopalachariah, and Jamnalal Bajaj. On the other side, promoting Hindi in the Devanagri script, as a language effectively in competition with Urdu in Nastaliq script, was, for example, P.D. Tandon, Babu Sampurnand, V.N. Tiwari, and Balkrishna Sharma. The debate, which reached its peak and raged through the HSS sessions of 1938-41 at Simla, Banaras, and Abohar, was conducted in and through the Hindi press itself, which tended to take the side of Hindi rather than Hindustani. Throughout, as is also evident in the writings of the likes of Tandon and Sampurnand (explored below), the Hindustani side was largely associated with a politics of religious community accommodation, a proto-secularism that embraced the essentially composite nature of India's political and social histories. The other side was more clearly aligned with a Hindu revivalist trend that worked both within and alongside mainstream political institutions such as the Indian National Congress.

This divide has been the subject of extensive academic commentary. And arguably, the division between Hindi and Urdu has, itself, been reinforced by subsequent literature exploring it. ${ }^{3}$ This article will not revisit this well-trodden terrain in terms of the languages themselves, but presents a survey of how the supposed Hindi-Urdu divide became an increasingly 'communal' issue, despite late colonial common knowledge about the largely non-religious/non-communal associations

1 The 'Hindi Literature Convention' — the principal organization promoting Hindi as a national language in India.

2 Sudha 6 January 1936.

3 The literature on the Hindi-Urdu debate is extensive but can be explored in depth. See for example, Rai 1984; King 1994; Rahman 1999; Faruqi 2001 
with each language. It will not look in detail at the means by which we arrive at a language that has distinctive overlapping provenance with a range of dialects and then to a bifurcated language based on script, but it will explore the politics that accompanied this division. In the first part of the article we will explore the ways in which Hindi and Urdu were mapped onto particular readings of India's political history, which became more closely related to religious community in the late colonial period. The second part of the article will examine the agencies and individuals who made this possible, exploring in particular the work and writings of Sampurnand and P.D. Tandon in the northern Indian state of Uttar Pradesh. The article will argue that particular forms of political change in the late colonial period shaped the polarization of Hindi and Urdu in debates about language. Specifically, the forms of anti-colonial and populist protest brought a new urgency to the promotion of a common vernacular at the right moment. Secondly, the forms of anti-colonial protest that dominated parts of northern India - the politically most significant regions of India - also generated forms of cultural nationalism that shaped Hindi promotion as a 'Hindu' project.

\section{DEFINING HINDI AND URDU ORIGINS}

Much of the debate around language, and specifically Hindi and Urdu, made references to deeper historical contexts. In many cases, this was a deliberate 'invention of tradition', which served the aesthetic purposes of literature; and as we will see below, key political publicists in the Hindi belt tied their nationalist mobilisation to historical developments of a pure dialect. As with most examples of nationalist hagiography, these histories obscured a far more complex reality, but themselves drew on certain myths of linguistic origin. Most linguistic scholars relate the variable roots of modern Hindi and Urdu to $12^{\text {th }}$ and $13^{\text {th }}$ Century Prakrits and dialects, which eventually developed to Khari Boli —a language spoken around Delhi in that period (Orsini 2009). The literary languages of those centuries, further east, were Awadhi and Brajbhasha. These variable dialects from that time, also related to their use in a range of contexts. What eventually became Urdu then (what language scholars describe as 'Hindvi'), had certain origins in the courts of Delhi and the regional courts to the East of that city (Awadhi and Brajbhasha). From these languages, a range of temporally shifting forms developed - Hindvi, Rekhta, Dakhani, which flourished in different areas at different times- in the Deccan in the $17^{\text {th }}$ Century and then in Delhi by the 18th.

The word 'Urdu', which first appeared in the late $18^{\text {th }}$ Century in the writings of the court of Shah Alam II of Delhi, was derived from the Turkish word 'camp'. But was a misleading term, in the sense that it was spoken beyond the permanent or shifting courts of regional rulers. As I will argue more below, the lack of accuracy here was, at least from the late $19^{\text {th }}$ Century a deliberate nationalist construction, in promoting the idea that Urdu was somehow 'new' and 'foreign' —a language brought to India by the Mughals. At the same time, Urdu did develop its own historical mythologies and literary associations. It became a recognized language of poetry 
in the 18th Century, which was thought to have a specific relationship to 'Persian', although in many respects this was an invented or 'pseudo' ancestor.

In the $18^{\text {th }}$ Century, Urdu emerged as a highly developed language of poetry, especially in the cities of Delhi and Lucknow, although it had flourished earlier in the Deccan. In some ways, this was a period of the rennaisance of the arts, including poetry. But these social and literary associations reinforced the idea that Urdu was somehow largely a language of governance and a tongue that had been 'changed' via association with the languages of invaders such as Arabic, Persian and Turkish. This is a distortion. 95\% of Urdu verbs have their roots in Sanskrit/Prakrit, which assimilated other languages into its dialects. The assumption of Mir Amman in 'Bagh-o-Bahar' (1802), later taken by up by Sir Syed Ahmed Khan and initially G A Grierson, that Urdu was largely a 'camp' language, was a popular misconception based in misreadings India's Muslim histories (Parekj 2011).

Far from being 'foreign' then, Urdu was an example of a local language, which was enriched with Persian literary currents, in fact displacing, gradually Persian itself as the language of elites. This issue of the extent to which language changed in relation to government is crucial —in the $19^{\text {th }}$ Century, the British dispensed with Persian as the language of governance and replaced it with English at the highest levels and the vernaculars at provincial and more local levels. For north India, from Bihar across to Punjab, this became Urdu for educated elites. It became much more of a prose language, used in journalism and the novel, which affected the significance of the language overall (Metcalf 29-37). Importantly, even organizations associated with the Hindu revival, such as the Arya Samaj generally used Urdu in the late $19^{\text {th }}$ Century. (Jones 1976).

Urdu in the Persian script was, then, doubtless the most important language of governance as the British began to establish their dominion over north India.

But as colonial power became increasingly complex and formal from the 1880s onwards, debates and decisions took place around 'vernacular' languages in the project of governance. The crucial phase in these language debates therefore corresponded to the critical transformations in colonial power and its administration on the ground around the turn of the Century. From this stage then, the association of language with its formal and informal 'use' in a multilingual setting, became a common point of reference in all discussions of political reform or constitutional advance. And it was from this position, that the politics of religious community came to be grafted too, on the question of language. We can see this most directly in the decisions of the Lt Governor of the NWP (later United Provinces), Anthony Macdonnell at the turn of the century. In 1900, Macdonnell took the decision to recognize the growing movement among publicists writing in the devanagri script, to establish the principle of an equality of Hindi and Urdu (Robinson 1974).

It was through the late $19^{\text {th }}$ Century, and into the early $20^{\text {th }}$ Century, that Urdu came to be more clearly associated with an older 'decadent' Nawabi culture (Metcalf 31), as the colonial state formalized rules of administration, attempted to root out local fiefdoms in some cases, and sought to rationalize the bases of its district administration. What David Lelyveld describes as 'language repertoires' — the use 
of Hindi or Urdu, or another dialect in different places or for different functions, became hardened in this phase of high imperialism (Lelyveld 107-117). The state, not being an autonomous entity as far as social change was concerned, was also responding to changes in communication technologies: Increases in the outputs and subjects of publishing and journalism not only created the physical medium for language propagation, but also became the vehicle for its discussion. Alongside new reading publics, were new forms of educational institution — school and university movements, epitomized by Syed Ahmed Khan's Aligarh movement, but also a range of revivalist institutions, such as the Gurukuls. These promoted new forms of cultural communication, which cut across and included writing, literature and music (Bhakle 2005). They also accompanied a growth in colonial anticipation of administrative Indianisation, as it attempted to rationalize its power, and the need to consider languages of administration and the courts.

Debates about which languages should be used in any particular region or across India, for education, commerce, the courts or administration, became particularly intense then just as the projects of regional and national publishing and journalism developed on a large scale. The journal, newspaper and tract made new forms of literature, or debates about language possible. And those with the skills and finance to publicise literary pursuits, were able to open up such debates about language. Print culture was therefore at the centre of these endeavours, and moreover, the issue of promoting vernaculars took place against the ever present power of English as a language of rule. Colonial hierarchies were developed through the 'high' literacy associated with English, and it was in reaction to this that literati across India promoted the vernaculars (Naregal 4-5). A central figure here was Syed Ahmed Khan in the debates around and promotion of Urdu. Attempts to define a clearer and dominant language in Nagri, were led by figures such as Harischandra Bharatendu in his promotion of a nationwide standardised Hindi through publishing and educational endeavours. For the Banaras based journalist, language, literature, religion and territory were all important in defining Hindu identity and he linked Sanskritised Hindi unambiguously to the Hindu community, and high caste Vaishnavite belief (Dalmia 432-434).

For most of the period up to the 1910s, the promotion of vernacular literatures, although it began to map, for example, Hindi onto the 'Hindu' community and Urdu to Muslims, did not generate lasting antagonism or controversy. It was not until the 1920s that, for example, movements for the promotion of Hindi began to be represented in earnest as communally competitive. The question as to how this came about and why such controversies appeared at all is extremely important and warrants careful consideration. How they were sustained will form the key theme of the arguments that follow. Certainly, the idea that the Hindu community might be connected to the promotion of Hindi was certainly something on the horizon of some of the key political publicists and leaders of the 1900s and 1910s. And in the 1888 session of the Indian National Congress, local issues such as the prevention of cow slaughter, as they applied to cities such as Allahabad, could still create the suggestion of a potential Hindu-Muslim divide (McLane 1997). Nevertheless, none of these developments created a uniform or broad sense that the interests of 
populations might be defined by ideas of religious difference; or that such differences existed uniformly across the entire subcontinent.

However, over the period up the 1910s, the issue of language increasingly entered into broader political discussions about the nation. For example, Hindi and the Devanagri script were at the centre of the project of late nineteenth-century Hindu revival. Dayanand Saraswati, the founder of the Arya Samaj, shared with Keshub Chandra Sen and a range of other Bengali leaders the desire to promote Hindi as a national language (Jones ch. 2-3). Moreover, the particular form of Hindi chosen by these intellectuals was important, and defined later language debates of the interwar period. Dayanand and figures like him, chose to concentrate on the promotion of a highly sanskritised Hindi, as part of the project for the rejuvenation of the 'true' or 'original' language of Hindus. This was despite the fact that most speakers in what came to be known as the Hindi belt would have spoken neither a standardised Hindi, nor one that was entirely devoid of Persian influences (Orsini Intr.)

A key element of Hindi promotion in the late nineteenth century revolved around script, particularly the use of Devanagri, and it was around the issue of script that some of the most important controversies of the period raged. An important institution, linked to the Arya Samaj in this project, was the Nagri Pracharini Sabha based in Banaras, whose first secretary, Shyam Sundar Das, claimed that the idea for the Sabha had come out of a meeting of the Samaj (Kumar 4-26). The Nagri Pracharini Sabha was a crucial institution at the end of the century in promoting Hindi as a language of the law courts in Uttar Pradesh. The Arya Samaj educational institutions, such as the Dayanand Anglo-Vedic Colleges were also instrumental in pushing the cause of Hindi. However, it was through Hindi journalism and literature that perhaps some of the most important progress in publicising Hindi in Devanagri was made. As well as Harischandra, the journals Brahman, Ksatriyapatrika, Hindi Pratap (edited by Balkrishna Bhatt), and Anandkadambini (edited by Babu Radhakrishnadas) were important in forwarding the cause of Hindi as the language of Hindus and as a national language (Dalmia 141-142). The cause of Hindi literati was also furthered by the Banaras Hindu University (BHU) project, driven by Madan Mohan Malaviya. In a manner similar to the Aligarh University, BHU started off in 1905 as a project that had a wider significance than just the establishment of a University. The finance for the University was the result of fund raising among India's Hindu landed interests across the Hindi belt, through north and central India. Like Aligarh, it was designed to impart a particular kind of cultural and 'national' education that brought with it qualities not to be found in other institutions. This related to the symbolic and religious significance of Banaras itself, a town considered as the heart of Hindu culture. BHU slowly developed too into the centre for the development of a standardised Hindi syllabi for teaching in other colleges around the country.

The promotion of Hindi and its relationship to Urdu was always executed in tension with the politics of region over nation. In other words, its proponents' claim that it constituted a 'national' language was always limited by Hindi's demographic and spatial reach. In exploring the largely 'invented' religious community associations between Hindi and Urdu therefore, we might also consider its relationship 
to, and similarities with parallel language movements in other parts of India. In western India for example, from the late 1870, Marathi was acquiring a dominant place in high literary pursuits in Bombay presidency, led by Chitpavan Brahman intellectuals. Over the same period that Hindi was being promoted, Marathi literature and the politics of bilingualism were furthered by voluntary associations, such as the Bombay Education Society, and the earlier Students' Literary and Scientific Society. These organisations acted as intermediaries between the local intelligentsia of urban centres and colonial officialdom, in producing a corpus of printed literature both in English and the vernaculars (Naregal 2001: 232-235). But in Pune, the high caste intelligentsia's intermediary position in the literary and educational sphere was challenged by the low — caste Satyashodak Samaj, led by Jotirao Phule, which used non literary public performances such as the tamasha, to contest high caste dominance of the municipalities (Naregal 268-270).

In India in the late colonial period, the politics of the journal was never far away from the politics of the streets and the assemblies. As anti-colonial nationalism extended and expanded beyond the initial petitioning movement of the Indian National Congress, the question of language also became more intensely political. In 1920, M.K. Gandhi rewrote the constitution of the Congress, lowering its membership fees to open the doors to wealthy peasants and workers. The language of that movement had been dominated by the cosmopolitan English-speaking elites of the Presidency cities. From 1920, if not much earlier, it was forced to keep pace with peasant and worker organisations that it had increasingly co-opted or swallowed as a means of building electoral strength and anti-state leverage (Pandey 1978). The languages of these communities were the vernaculars. Simultaneously, a new generation of publicists working in Hindi or Urdu took the place of provincial political mobilisations, as the 1920s-30s system of dyarchy pushed the foci of power more into the provinces and districts. These leaders had cut their political teeth in the city and district organisations, or had been educated through vernacular medium schools. Most importantly, they were representatives not of the large urban interests of previous years, but increasingly of agrarian communities, small traders, blue — collar workers and to some extent, the landless poor (Gooptu 2001; Gould 2004: Intr).

This was important context then, for the development of political controversy around language, not least because the medium of political rhetoric itself drew in the question of vernaculars. On the one hand the question of Hindi's place, for example, in the new political structures and societies of north India, created new debates about 'national' language and how the promotion of particular vernaculars encouraged forms of cultural autonomy. On the other hand, the use of vernaculars assisted in the development of political rhetoric that more clearly drew on community themes, religious questions, and issues of ethnic difference. This is not to argue that Hindi or Urdu were inherently vehicles for communal expression. Rather, the development of mass politicization in a context of language hierarchies, in which English was placed at the centre of urban cosmopolitanism, endowed vernaculars with the power of cultural difference. Such a politics easily wedded the issue of language to notions of anti-western mobilization, a critique of the presupposed structures of modernity, and the use of tradition to defend 'national' culture. 
The debate around Hindi was also related to its inherent limitations, in the sense that there were many arguments against it ever fulfilling a role as a truly national language. It had to fill the extended 'national' space that the larger British presence had helped to establish, but it was by no means the lingua franca in all of those regions. The 'Hindi belt' itself was actually not uniformly Hindi speaking: it is still made up of related dialects such as Bhojpuri. Hindi then was a language that had enough mass and speakers at the commercial epicentre, to morph into a 'language' and was a very large regional language therefore, but not easily a 'national' one. The idea of it being based in 'Sanskrit' was also, in some respects, a fiction. The idea of 'sanskritized' Hindi was actually something quite modern, and a response to the idea of Hindi being sidelined by English — speaking elites in India. This led to deliberate abstruseness, which was used to change, and artificially bolster a natural language. This also involved an 'ethnic cleansing' of Urdu from the language, and a like for like unnatural translation of English terms into Sanskrit.

\section{HINDI, HINDUISM AND CULTURAL EXCLUSIVISM}

In writing about the development of language politics in late nineteenth and early twentieth century India, historians and literary scholars have frequently made use of the idea of the 'public sphere' (Orsini 2009; Naregal 2001). This framework presents the idea of a hegemonic middle — class public, who developed voluntary institutions and publishing enterprises which defined the idea of public space in new ways in India. However, most scholars have also sought to complicate the traditional model of the public sphere presented by Jurgen Habermas in looking at European society in the modern period. Francesca Orsini, for example, has argued with reference to the Hindi literary sphere, that instead of a twofold division of 'public' and 'private', we might consider Indian society in terms of three layers — public, private and 'customary'. For Orsini, this 'customary' sphere related to cultural practices and beliefs that unevenly overlapped between both private and public matters (Orsini Intr.) Certainly, the development of literary spheres in India was very different to the experience of most European states, not least because of the complication of bilingualism among the social and literary elites.

The symbolic power of the English language, and its association with governance in India, also recreated forms of colonial hierarchy in cultural affairs, and in popular media. Perhaps most significantly, the sphere of vernacular literary pursuits was more commonly associated by the politically powerful in India with the politics of the disadvantaged. ${ }^{4}$ And just as appeals to the grassroots were often

${ }^{4}$ This was a constant refrain of M.K. Gandhi in the 1910s and 1920s, who associated the gulf between India's urban educated and rural peasant communities in terms of knowledge of vernaculars, and in particular, Hindi. See 'Gandhi's Speech on Non-Cooperation in Calcutta', 13 December 1920, in Gandhi 1972: vol. 22/25, pp. 84-89. 
made via a religious idiom, so too, did the use of Hindi, Urdu, Marathi, Bengali, or other regional languages, presuppose a different level of political mobilisation, which was often deliberately divorced from western notions of secular mobilisation. Finally, the promotion of particular vernaculars involved projects of standardisation and definition, which reinforced institution and organisation building as a means of asserting particular kinds of collective identities. Insofar as language movements were concerned with the future shape of state power, as well as literature, the arts and 'culture', such institutions were tied to the whole process too, of how different communities shaped their approach to an imagined free Indian state.

There was also a sense in which the promotion of Hindi was about the development of a popular vernacular - an idiom used outside the formal constitutional structures of politics. In this sense, as Orsini and A. Rajagopal also argue, the politics of Hindi runs alongside this dualistic English/vernacular divide in India. For Orsini, this was also about opening out forms of peasant mobilisation, via the politics of figures such as Sahajanand Saraswati and the Kisan Sabha movement in Eastern Uttar Pradesh and Bihar (Orsini ch 3; Rajagopal 1999). Equally, we can talk about an urban popular idiom of politics in this region, via the work of Nandini Gooptu and the mobilisation of lower castes in the towns and cities (Gooptu 2001). However it is via the political idiom of Hindi too, that we see a specific form of cultural exclusivism emerging from the 1930s, just as the idea of non-constitutional mobilisation was widening out. This final part of the paper will look at that via religious symbolism and the press and via the political writings and thinking of two leaders in particular - P.D. Tandon, and Babu Sampurnanand,

In the early stages of journalism in the Indian vernaculars from the early to mid $19^{\text {th }}$ century, language use in the media clearly reflected the role of each language in governance. In 1870 for example, there were 15 Urdu papers with a circulation of 2050, and 8 Hindi ones with a circulation of 384. From the 1910s onwards however, the Hindi weeklies and dailies started to expand - in this sense catching up with the growing political importance of the Hindi belt as a region and the language itself, but in important ways, defining the conflict between the two branches of the language.

Some key new publications were started from the early part of the $20^{\text {th }}$ century into the 1920s, for example, Abhyuday (Malaviya) in 1907; Ganesh Vidyarthi's Pratap, (1913 weekly, and daily from 1920), V.N. Tivari's Bharat, Prabha, Vartman, and Adhars all founded around 1920, and K.D. Paliwal's Sainik (1925 weekly, 1935 daily) from Agra. Banaras, the home of the Nagri Pracharini Sabha was a key city for Hindi papers, and it was from here that Aaj (1920) Jagaran, (1929), and Hams (1930) were published. In Lucknow, after the 1924 riot we have Arti and Anand, which started as a result of the riot there and which displaced Hamdam somewhat (which was Urdu).

These newspapers were promoted and supported then, by a specific kind of journalist/publicist, often with a political career, and in some cases with leanings towards forms of cultural nationalism that derived from Hindi's popularization. This included leaders and publicists like K.D. Paliwal, M.M. Malaviya, P.D. Tandon, and V.N. Tivari. These editors and political publicists often promoted forms of 
cultural nationalism which tied festivals and local events to national movements, as a form of popular mobilization. For example, Paliwal's Sainik published in Agra, ran a series of articles at the beginning of Holi in which the imagery of religious symbolism was given a kind of political edge - Gandhi would dye the bureaucracy with splashes of his blood. Both this paper and the Abhudhaya which was published in Allahabad, talked about Holi in terms of the demon that still existed in India today, Hiranyakashyup (Gould ch 2). In other respects, these newspapers used the occasion of local events to tie support for anti-colonial protest to activities such as cloth boycotts, especially during the early 1930s.

\section{SAMPURNANAND AND TANDON}

We might more effectively look at these processes in the dual promotion of Hindi with forms of anti-colonial mobilization/political ideology, by exploring specific leaders in the period, and particularly from the regions where the Hindi debate was most prominent - The United Provinces or Uttar Pradesh. The final part of the paper will explore this in relation to two prominent figures in Uttar Pradesh -P.D. Tandon and Sampurnanand. Both leaders applied certain assumptions about Indian society, which presupposed the efficacy of vernacular forms of mobilization. The common man could be reached via vernaculars through folk forms or a religious idiom. This, interestingly, took on a peculiarly colonial idea about the organisation of Indian society overall, in which the politics of the poor was associated with premodernity and religious community. Through the use of the vernacular, language itself became a means of expressing certain kinds of boundaries, rights and forms of political behaviour. In the case of Sampurnanad, as we will see, this was that the use of Hindi allowed for the promotion of a Hindu organacist view of the nation. In the case of Tandon, this was about the ways in which a particular form of standardised Hindi should be seen as a framework for full citizenship rights. In both cases, it involved the representation of Urdu in terms of decadence and decline.

Babu Sampurnanand was from a kayastha family and would have been Urdu speaking but his father insisted on teaching him Hindi. He was drawn to yoga and toyed with the idea of joining the Radhaswami sect and in his early career worked as a teacher and university lecturer. In April 1930, he was appointed 'dictator' of the Banaras Congress, and in 1938 was appointed education minister in the United Provinces Ministry. Sampurnanand was known in the early to mid 1930s as a Congress socialist, although it was an interpretation of that philosophy that had distinct north Indian characteristics (Gould ch 2). The implications of his socialism, was that notions of social equality and cohesion were rooted, specifically, in Vedantic Hindu religious traditions, and the notion of an oversoul of the universe (Virat Purusha). This informed his writing on a range of larger political issues, including the role of democracy in India. It also generated an important take on 'secularism', as a phenomenon, Sampurnanand believed, known by ancient India long before western Europe. Added to this were his organicist ideas about the nation in relation to Hindu culture and society: Indian society, he argued, had historically been 
at its weakest when influenced by semitic religions like Islam and Christianity. $\mathrm{He}$ suggested that Hindu culture was more 'confident' when not influenced by these groups (Sampurnanand 1939).

The wider implications of Sampurnanand's politics was seen when he was in office as Education Minister in the UP, and he decided to implement the Wardha scheme across the province. The scheme tended to present, according to Muslim organisations, a one-sided view of history and focused very much on the promotion of Hindi as a medium of education. This was reflected in Sampurnanand's own views about Urdu, which he found to be 'unacceptable... and not suitable to be adopted as a national language' (Sampurnanand 1962: 88-92). At the end of August 1938 at the Kashi Nagri Pracharini Sabha, Sampurnand talked too about the qualitative differences between Hindi and Urdu, and made the point that there should be a retention of Sanskrit in the language, for the sake of speakers from other regions like Maharashtra, Gujarat and Bengal. ${ }^{5}$

The policies of Sampurnanand towards Urdu led to a reaction among Muslim organisations - some picking up, specifically on the Wardha scheme and the promotion of Sanskrit, and others, such as the Jamiat-ul-Ulema- more generally about the attitude of the Education Minister to Urdu. This formed the backdrop to a more direct and focused Hindi campaign for Sampurnanand after Independence. As Chief Minister of UP between 1954 and 1960, he helped to implement a range of state - level policies that cemented a Hindi- only policy, over-riding instructions from the Central government to allow for the promotion of Urdu as a minority language of instruction in educational institutions (Jaffrelot 161).

Sampurnanand's promotion of a mono-linguistic culture in north India was, in the main, focused on education and culture. But for another key Congress leader and contemporary, Purushottam Das Tandon it entailed the rejection of Indo-Persian cultural influences on the idea of the citizen. P.D. Tandon was best known for his successful challenge to Jawaharlal Nehru as President of the Congress in 1950, with the backing of Vallabhai Patel, but his political career spanned back to the 1900s. He first represented the city of Allahabad at the All India Congress Committee in 1906, and was involved in the main Gandhian protests of the 1920s and 1930s. Throughout the 1940s, although seen as a radical in the Congress in these earlier years, he came to be associated with spin-off Hindu organisations. Tandon also maintained a keen interest in the promotion of Hindi as a national language, but as we will see below, combined it with a form of majoritarian politics, which was often channeled through the HSS. ${ }^{6}$

Tandon's espousal of 'Hindu' unity linked into a range of other cultural activities for him, and it is here that the significance of this politics for the idea of tember 1938

5 Sampurnanand Papers (Varanasi Regional Archives), Sampurnanand to Gandhi, 5 Sep-

6 'Appreciation of the Political Situation' (hereafter APS) 11 May 1945; 25 May 1945. 'Confidential Report', Fortnightly Report for the first half of April 1945, 19 April 1945 Frampton Papers, Centre of South Asian Studies, Cambridge (hereafter SAS). 
the citizen plays out. The relationship between active opposition to Pakistan and the promotion of a majoritarian position on Hindi were directly related, and espoused simultaneously. For example, Tandon's chairmanship of the $31^{\text {st }}$ HSS between 17 and 19 May 1943, entertained amongst its alumni representatives of the Mahabir Dal and RSS, and contained speeches criticizing the Muslim League. ${ }^{7}$ In April 1945, as well as collecting funds for a Hindi Sahitya Sammelan Bhavan in Jaipur, he supported Sampurnanand's criticism, via the UP Provincial Sammelan, of the pro-Urdu policy at All-India Radio. ${ }^{8}$ In the same month at the Kangri Gurukul in the western UP district of Saharanpur Tandon was again vocal about his opposition to Gandhian non-violence. ${ }^{9}$ The promotion of Hindi then, became a vehicle for the development of an exclusively defined, majoritarian concept of citizenship in which linguistic difference potentially positioned the nation's denizens. At open session of the HSS held in Bombay in December 1947, attended among others by V.D. Savarkar, Tandon had suggested that there was still an attempt to satisfy Muslims in relation to the national language, and that in the past the British had encouraged the idea that their culture was different. At that same meeting, Seth Govind Das argued that while Muslims were voicing their loyalty to the Indian Union, they were still following the same old policy and that if they did not want to show loyalty, they should go to Pakistan ("Samelan" 1948).

But it was shortly after independence that these totalizing representations of Indian culture were developed most directly into exclusive and ethnicised ideas of citizenship. At an open meeting of the HSS in the spring of 1948, Tandon suggested that use of Hindi should be a means of testing Muslim loyalty to India. If the Socialists supported Urdu-inflected Hindustani, ${ }^{10}$ Tandon argued, they would be continuing to support the two-nation theory. The country's salvation lay instead in everyone having, in Tandon's words, 'one culture and civilization'. Muslims, therefore, had to "own the Indian culture and civilization like they have done in China." The partition of the country for Tandon was an illustration of the failure of this monolithic nation, which naturally revolved around Hindu culture. In the UP Assembly, Tandon argued that partition was due to the past sins of Hindus and that if they did not open the doors of Hinduism to Muslims, they would experience worse grief.

Tandon's correspondence also shows support for organizations that sought to directly question the citizenship rights of Muslims, including an All-India Refu-

7 APS 12 February; 21 May 1943.

${ }^{8}$ APS 11 May 1945; 25 May 1945. 'Confidential Report', Fortnightly Report for the first half of April 1945, 19 April 1945 Frampton Papers, SAS.

9 'Confidential Report', Fortnightly Report for the first half of April 1945, 19 April 1945 Frampton Papers, SAS.

10 The promotion of Hindustani related to a section of the Hindi Sahitya Sammelan in the late colonial period, who favoured the idea of a national vernacular which embraced vocabulary drawn from Urdu. This group opposed those in the Sammelan, such as Tandon and Sampurnanand who argued for a 'pure' and more sanskritized Hindi. See Orsini 2009. 
gee Association (AIRA), a Sindhi-dominated organisation headed by Choitram P Gidwani. The Association had developed out of refugee agitations for property compensation, and directly lobbied the Prime Minister's Office. Tandon was seen as a key supporter, with the Association seeking his help in rent disputes, ${ }^{11}$ and in preventing the recovery of income tax demands issued on Sindhi refugees by the Pakistani authorities. ${ }^{12}$ Indeed, his stance on refugees and Muslim properties was a key dynamic of Tandon's dispute with Nehru himself and the AIRA spared no ire in denouncing Nehru as a man whose "culture" was Muslim and who showed too much open "appeasement" of Pakistan. ${ }^{13}$

The role of these organisations had a material effect on the substantive citizenship rights of Muslim communities. In 1950, the Sindhi Hindu Refugee Panchayat, based in Dugapur Camp, Jaipur, wrote to Tandon for help in preventing Muslims from selling and mortgaging properties in Rajasthan. The Panchayat provided lists of Muslim government servants who had retained properties but migrated, or who had "deceived refugees". ${ }^{14}$ In 1950, Tandon presided over the AllIndia Refugee Conference in Delhi, at which the speech of Choithram P. Gidwani complained of inadequacy of refugee loans, suggested that the evacuee property law had failed to prevent a "drain of crores of rupees from India to Pakistan", and charged the Jamiat-ul-Ulema with agitation against the ordinance. Gidwani summed up his list of accusations with the doubt that "elements returning to India who have breathed the poisonous atmosphere of Pakistan will ever remain loyal to our country." 15

Tandon helped rich and poor alike manoeuvre the everyday state in this majoritarian world of citizens' rights. Other correspondents to Tandon requested help in acquiring evacuee property, such as one P.R. Kishanchand, also from Sindh, who wanted help acquiring a shop in Kanpur in $1952 ;{ }^{16}$ or the letter of complaint sent by the District Refugee Corporation, Jhansi about a rationing officer (B.R. Sharma) and the inadequacy of his call for tenders for evacuee properties. ${ }^{17}$ This led to a host of other smaller colonies of displaced persons seeking Tandon's support, including the poorly-provisioned Lajpatnagar Panchayat Settlement near Delhi which requested a

${ }^{11}$ Choitram P Gidwani All India Refugee Association to Tandon, 23 July 1952, Tandon Papers, File 301 National Archives of India (hereafter NIA).

${ }_{12}$ Statement of the Displaced Income-tax payers' association, New Delhi. Draft Resolutions of the All India refugee Conference, 29-30 July 1950, Tandon Papers, File 301 NAI.

${ }^{13}$ All India Refugee Conference, 29-30 July 1950, General comments on the resolutions. Tandon Papers, File 301 NAI.

${ }^{14}$ From representatives of the Sindhi Hindu Refugee Panchayat, Jaipur, Durgapur Camp, Gopaldas H. Ladhani, Congress Social Worker, to Tandon. 29 January 1950, Tandon Papers, File 301 NAI.

${ }^{15}$ Speech of Dr. Choithram P Gidwani, Chairman Reception Committee, All India Refugee Conference, Delhi, 29-30 July 1950, Tandon Papers, File 134 NAI.

${ }_{16}$ P.R. Kishanchand to PDT, 19 December 1952, Tandon Papers, File 128 NAI.

${ }_{17}$ District Refugee Cooperative Society to B.R. Sharma, TRO cum R and R Officer, 9 January 1950, Tandon Papers, File 119, NAI. 
training or work centre. ${ }^{18}$ Supporting Hindu refugee organisations also meant that Tandon became a forum of partisan complaints about 'Muslim' brutality. His papers are littered with accounts of such alleged excesses. ${ }^{19}$ In extension of this patronage, Tandon was targeted by members of the RSS calling to be reinstated in government service following the ban on the organisation, including one missive from a Sindhi migrant seeking help for his son who had been jailed as an RSS member. ${ }^{20}$ Another letter compared the apparent "tolerance" shown to Pakistani Muslims to the treatment of RSS men. ${ }^{21}$ Other correspondents to the leader sought support for complaints against Muslim government servants in Delhi and Uttar Pradesh. ${ }^{22}$ Later, Tandon was even a sympathetic voice for the likes of Baburao Patel, a columnist who wrote a strongly anti-Muslim article in Film India in March 1952, against the Pakistani documentary Josh-e-Jehad (The Passion of Religious Crusade). ${ }^{23}$

\section{CONCLUSION}

It is possible to write a history of Indian politics for the second and third quarters of the 20th Century as a history of language. The question of which vernacular should be promoted as the principal language of governance, the courts and administration, and thereby the putative 'national' language, connected to a wide range of other issues surrounding community, political authority, institution building and state patronage. Most importantly, as the period progressed, new, more popular forms of vernacular politics mobilized larger and more diverse constituencies, and the issue of language appeared yet more urgent. The role of the rapidly expanding press in the interwar years was central to this, both in terms of providing the medium for language propagation, but also in the linguistic forms that the content of new presses promoted: particular forms of symbolism, and the connection of linguistic forms to social questions imbued Hindi in particular in north India, with a specific role in creating new spheres of public debate.

There was no necessary reason, given the very complex linguistic roots of Hindi and Urdu, that this explosion in interest in language should have provoked religious community — based controversy. Both languages, by their nature, were described as homogenous or standardized in a way that distorted not only the wide

18 Lajpatnagar Panchayat Statement, nd, Tandon Papers, File 301 NAI.

19 For example, Statement of S S Bhasin, of district Campbellpur, 22 August 1947 (at present taking shelter under the roof of Arya Samaj, Old Hospital Road, Jammu), in Tandon Papers, file 29, NAI. This letter described Hindu deaths near Wazirabad.

${ }^{20}$ L.H. Ajwani, Prof of English, Sind College, Karachi to PDT, 21 November 1947, Tandon Papers, file 29, NAI.

${ }^{21}$ S. No 734, S.C. Sharma, Tundla, to PDT - 24 July 1950, Tandon Papers, file 28, NAI. File 29, NAI.

22 'The responsible citizens of Ghaziabad' to Tandon, 21 September 1947, Tandon Papers,

${ }^{23}$ Baburao Patel to M.I. Quadri, 24 March 1952, in Tandon Papers, file 11, NAI. 
variations in dialect and form across space, but also through time. Clearly, different forms of both languages were used in different modes of social life. But these differences might not have had an effect on relations between Hindus and Muslims without the emergence of new forms of Hindi populism, promoted by a range of figures in the Congress movement itself. The process of linguistic standardization for Hindi went hand in hand with a quest to find the 'pure' elements of Indian civilization - a set practices and ways of life that distinguished it from foreign rulers and invaders. In this sense, the Hindi movement came to polarize around a debate about exclusivism versus inclusivism - the very same parameters of discussion that shaped ideas about the future Indian citizen.

Reviews sent to author: 17 November 2017 Revised paper accepted for publication: 2 February 2018 


\section{REFERENCES}

"Maintain Ethical Standard in Elections: Speaker Tandon's Plea", National Herald, 20 April 1948. "Sammelan Demands Hindi in Devanagri as Lingua Franca", National Herald, 1 January 1948.

Bhakle, Janaki. Two Men and Music: Nationalism in the Making of an Indian Classical Tradition. Oxford University Press, 2005.

Dalmia, Vasudha. The Nationalisation of Hindu Traditions: Bharatendu Hariscandra and Nineteenth Century Banaras. Oxford University Press, 1997.

FARUQI, Shamsur Rahman. Early Urdu Literary Culture and History. Oxford University Press, 2001.

Gandhi, M.K. Collected Works of Mahatma Gandhi, Indian Ministry of information, 1972.

Gooptu, Nandini The politics of the Urban Poor in Early Twentieth Century India. Cambridge University Press, 2001.

Gould, William. Hindu Nationalism and the Language of Politics in Late Colonial India. Cambridge University Press, 2004.

Jones, Kenneth W. Arya Dharm: Hindu Consciousness in $19^{\text {th }}$ Century Punjab. University of California Press, 1976.

KIng, Christopher. One Language, Two Scripts: The Hindi Movement in $19^{\text {th }}$ Century North India. Oxford University Press, 1994.

Kumar, Krishna. 'Hindu Revivalism and Education in North-Central India', Social Scientist, vol. 18, No. 10 (Oct, 1990), pp. 4-26.

Lelyveld, David. “Zuban-e Urdu-e Mu'alla and the Idol of Linguistic Origins', Annual of Urdu Studies, Vol. 9 (1994), pp. 107-117.

McLane, John. Indian Nationalism and The Early Congress (Princeton: Princeton University Press, 1977).

Metcalf, Barbara. 'Urdu in India in the 21st Century', Social Scientist, 31, 5-6 (May-June 2003), pp. 29-37.

Naregal, Veena. Language Politics, Elites and the Public Sphere: Western India under Colonialism. Anthem, 2001.

Orsini, Francesca. The Hindi Public Sphere (1920-1940): Language and Literature in the Age of Nationalism. Oxford University Press, 2009.

Pandey, Gyanendra. The Ascendancy of the Congress in Uttar Pradesh: A Study in Imperfect Mobilisation. Oxford University Press, 1978.

Parekh, Rauf. “Urdu's origin: it's not a 'camp language” Dawn, 17 December 2011. https://www. dawn.com/news/681263. Accessed 5 February 2018.

Rahman, Tariq. "The Teaching of Urdu in British India”, Annual of Urdu Studies, 15, (1999).

RaI, Amrit. A House Divided: The origin and development of Hindi/Hindavi. Oxford University Press, 1984.

Rajagopal. Arvind. Politics After Television: Hindu Nationalism and the Reshaping of the Public in India. Cambridge University Press, 1999.

Robinson, Francis. Separatism Among Indian Muslims: The Politics of the United Provinces's Muslims, 1860-1923. Cambridge University Press, 1974.

Sampurnanand, Samajavada. Banaras, 1939.

_ 'Our National Language', in Memories and Reflections. Bombay, 1962, pp. 88-92. 